\title{
A organizaç̃o pan-Americana da saúde comemora o seu CENTENARIO EM DEZEMBRo de 2002
}

\author{
Isabel Amélia Costa Mendes ${ }^{1}$
}

Maria Helena Palucci Marziale ${ }^{2}$

A Organização Pan-Americana da Saúde (OPS) é o organismo internacional de saúde pública mais antigo do mundo, comemorando, em dezembro de 2002, cem anos de existência, caracterizados por um caminho trilhado no sentido de uma busca contínua pela melhoria da saúde e nível de vida da população das Américas.

Desde 1945, com a criação da Organização das Nações Unidas - ONU, a OPS integrou-se ao Sistema da ONU, exercendo também a função de órgão regional da Organização Mundial da Saúde no contexto inter-americano. São membros da OPS: Antigua e Barbuda, Argentina, Bahamas, Barbados, Belize, Bolívia, Brasil, Canadá, Chile, Colômbia, Costa Rica, Cuba, Dominica, Equador, El Salvador, Estados Unidos da América, Granada, Guatemala, Guiana, Haiti, Honduras, Jamaica, México, Nicarágua, Panamá, Paraguai, Per, República Dominicana, Saint Kitts e Nevis, Santa Lucia, San Vicente e Granadinas, Suriname, Trinidad e Tobago, Uruguai e Venezuela. Além dos Estados mencionados, os Governos da França, Países Baixos e Reino Unido também participam de sua Assembléia Geral, Porto Rico é membro associado e Espanha e Portugal são membros observadores.

A sede da OPS localiza-se em Washington, EUA, de onde são emanadas diretrizes de ações aos seus 27 escritórios de representação regional e nove centros científicos e técnicos. A OPS colabora com os países membros, incentivando o intercâmbio de informação técnica, auxiliando-os a mobilizar recursos destinados à saúde e prestando assistência técnica em áreas específicas. Nesse sentido, atua em cooperação com os Ministérios de Saúde dos Estados Membros, outros governos e organismos internacionais, organizações não governamentais, universidades, grupos da comunidade e outras entidades com o propósito de fortalecer os sistemas de saúde.

Os programas desenvolvidos pela OPS centram-se na garantia da eqüidade, diminuição da mortalidade infantil, capacidade epidemiológica, vacinação, difusão de informação, controle de doenças, melhoramento nutricional e saúde preventiva. Para o atingimento desses fins, a Enfermagem exerce um papel de liderança, através de ações relacionadas à prática de consultoria no âmbito da própria OPS, como também da atuação direta nos sistemas de saúde dos Estados Membros, promovendo a atenção integral à saúde em todos os seus níveis.

Em suma, nesses cem anos, a OPS vem priorizando decisões estratégicas visando a promoção do desenvolvimento dos países das Américas e facilitando a execução de ações efetivas na área da saúde.

A Escola de Enfermagem de Ribeirão Preto da Universidade de São Paulo, parceira da OPS e OMS na condição de Centro Colaborador da OMS para o Desenvolvimento da Pesquisa em Enfermagem, sente-se honrada e compartilha da alegria dessa comemoração!

Editores da Revista Latino-Americana de Enfermagem da Escola de Enfermagem de Ribeirão Preto, da Universidade de São Paulo, Centro Colaborador da OMS para o desenvolvimento da pesquisa em enfermagem: ${ }^{1}$ Professor Titular, e-mail: iamendes@eerp.usp.br; ${ }^{2}$ Professor LivreDocente, e-mail: marziale@eerp.usp.br 


\section{THE PAN-AMERICAN HEALTH ORGANIZATION CELEBRATES ITS 100th ANNIVERSARY IN DECEMBER 2002}

Isabel Amélia Costa Mendes ${ }^{1}$

Maria Helena Palucci Marziale ${ }^{2}$

The Pan-American Health Organization (PAHO) is the oldest international public health agency in the world, and, in December 2002, the organization celebrated its 100 years of existence, which has been characterized by efforts towards the continuous search for the improvement of health and life standards of the population in the Americas.

Since 1945, with the creation of the United Nations Organization - UN, PAHO has integrated the UN System by also playing the role of a regional agency of the World Health Organization in the inter-American context. The following are member countries of PAHO: Antigua and Barbuda, Argentina, The Bahamas, Barbados, Belize, Bolivia, Brazil, Canada, Chile, Colombia, Costa Rica, Cuba, Dominica, Ecuador, El Salvador, The United States of America, Granada, Guatemala, Guyana, Haiti, Honduras, Jamaica, Mexico, Nicaragua, Panama, Paraguay, Per, The Dominican Republic, Saint Kitts and Nevis, Saint Lucia, San Vicente and Granadinas, Suriname, Trinidad and Tobago, Uruguay and Venezuela. In addition to the aforementioned States, the government of France, The Netherlands and The United Kingdom also participate in its General Assembly, Puerto Rico is an associate member and Spain and Portugal are observing members.

The PAHO headquarters is located in Washington D.C., USA, which is where the action guidelines to the 27 regional representation offices and nine scientific and technical centers originate. PAHO collaborates with its member states by encouraging the exchange of technical information, helping them to mobilize health resources and technical assistance in specific areas. In this aspect, it acts in cooperation with the Health Departments of the members States, other governments and international agencies, non-governmental organizations, universities, community groups and other entities with the purpose to strengthen health systems.

The programs developed by PAHO focus on the assurance of equity, reduction in child mortality, epidemiological capacity, vaccination, information dissemination, disease control, nutritional improvement and preventive health. In order to achieve these goals, Nursing plays a leading role through actions related to the consultancy practice in the extent of PAHO itself, as well as by means of direct action in the health systems of the member States by promoting integral health care in all levels.

In summary, during these 100 years, $\mathrm{PAHO}$ has prioritized strategic decisions aiming at promoting development in the American countries and facilitating the execution of effective actions in the health field.

The University of São Paulo at Ribeirão Preto College of Nursing, a PAHO and WHO partner as a WHO Collaborating Centre for Nursing Research Development, is honored and shares the joy of this celebration!

Editors of Latin American Journal of Nursing of Ribeirão Preto of the University of São Paulo at Ribeirão Preto College of Nursing - WHO Collaborating Centre for Nursing Research Development: ${ }^{1}$ Full Professor, e-mail: iamendes@eerp.usp.br; ${ }^{2}$ Associate Professor, e-mail: marziale@eerp.usp.br 


\section{La ORganización panamericana de la salud celebra su CENTENARIO EN DICIEMBRE DE 2002}

Isabel Amélia Costa Mendes ${ }^{1}$

Maria Helena Palucci Marziale ${ }^{2}$

La Organización Panamericana de la Salud (OPS) es el organismo internacional de salud pública más antiguo del mundo, celebrando en diciembre del 2002, cien años de existencia, caracterizados por un vasto camino en la búsqueda continua del mejoramiento de la salud y el nivel de vida de la población de las Américas.

Desde 1945, con la creación de la Organización de las Naciones Unidas - ONU, la OPS se integró al sistema de la ONU, ejerciendo también la función de órgano regional de la Organización Mundial de la Salud en el contexto Interamericano. Son miembros de la OPS: Antigua y Barbuda, Argentina, Bahamas, Barbados, Belice, Bolivia, Brasil, Canadá, Chile, Colombia, Costa Rica, Cuba, Dominica, Ecuador, El Salvador, Estados Unidos da América, Granada, Guatemala, Guyana, Haití, Honduras, Jamaica, México, Nicaragua, Panamá, Paraguay, Perú, República Dominicana, Saint Kitts \& Nevis, Santa Lucia, San Vicente e Granadinas, Suriname, Trinidad \& Tobago, Uruguay y Venezuela. Además de los Estados mencionados, los Gobiernos de Francia, Países Bajos y Reino Unido también participan en su Asamblea General, Puerto Rico es miembro asociado e España y Portugal son miembros observadores.

La sede de la OPS se localiza en Washington, EUA, de donde salen las directrices de acciones a sus 27 oficinas de representación regional y nueve centros científicos y técnicos. La OPS colabora con los países miembros, incentivando el intercambio de información técnica, ayudándolos a movilizar recursos destinados a la salud y prestando atención técnica en áreas especificas. En ese sentido, actúa en cooperación con los Ministerios de Salud de los Estados miembros, otros gobiernos y organismos internacionales, organizaciones no gubernamentales, universidades, grupos de la comunidad y otras entidades con el propósito de fortalecer los sistemas de salud.

Los programas desarrollados por la OPS se centran en la garantía de la equidad, disminución de la mortalidad infantil, capacidad epidemiológica, vacunación, difusión de información, control de enfermedades, mejoramiento nutricional y salud preventiva. Para el logro de estos fines, Enfermería ejerce un papel de liderazgo, a través de acciones relacionadas con la practica de consultorías en el ámbito de la propia OPS, como también de la actuación directa en los sistemas de salud de los Estados miembros, promoviendo la atención integral a la salud en todos sus niveles.

En resumen, en estos cien años, la OPS viene priorizando decisiones estratégicas buscando la promoción en el desarrollo de los países de las Américas y facilitando la ejecución de acciones efectivas en el área de la salud.

La Escuela de Enfermería de Ribeirão Preto de la Universidad de São Paulo, socia de la OPS y de la OMS en condición de Centro Colaborador de la OMS para el Desarrollo de la Investigación en Enfermería, se siente honrada y comparte la alegría de esta celebración!

Editores de la Revista Latinoamericana de Enfermería de la Escuela de Enfermería de Ribeirão Preto de la Universidad de São Paulo, Centro Colaborador de la OMS para el desarrollo de la investigación en enfermería: ${ }^{1}$ Professor Titular, correo electrónico: iamendes@eerp.usp.br;

${ }^{2}$ Professor Libre-Docente, correo electrónico: marziale@eerp.usp.br 
